\title{
A safe flight for children through COVID-19 disaster: keeping our mind open!
}

\author{
J. Peter de Winter ${ }^{1,2} \cdot$ Derek de Winter $^{3} \cdot$ Valentina Bollati $^{4} \cdot$ Gregorio P. Milani ${ }^{5,6}$ \\ Published online: 2 May 2020 \\ (C) Springer-Verlag GmbH Germany, part of Springer Nature 2020
}

In 1972 the pilots of Eastern Air Lines Flight 401 to Miami International Airport noticed that the nose wheel of the landing gear was not locked properly in place. While the crew was troubleshooting the anomalous gear indicator and the autopilot was disconnected, they did not notice that the aircraft was gradually losing altitude until it finally crashed into the Florida Everglades. The improper division of duties on the flight deck, the exclusive focus on one aspect of the flight security, and the failure to think about all available resources for a safe landing was underlying this tragedy [2]. This event might be of help to face the current coronavirus induced disease-19 (Covid-19) crisis. Nowadays, most countries affected by Covid-19 are in lockdown. Standard measures put in place are travel bans, working from home, closure of schools, and, overall, limiting social contacts as much as possible. It is necessary to contrast the immediate consequences of Covid-19 pandemics such as a shortage of intensive care units and a high death toll. However, both health authorities and care providers should not forget the dormant and mostly unseen effects of these measurements, especially on vulnerable individuals. Through this editorial we would like to encourage its

Communicated by Peter de Winter

J. Peter de Winter

editor-ejp@spaarnegasthuis.nl

1 Department of Pediatrics, Spaarne Gasthuis, Hoofddorp/ Haarlem, The Netherlands

2 Department of Development and Regeneration, KU Leuven, Leuven, Belgium

3 Faculty of Medicine, Amsterdam UMC, Amsterdam, The Netherlands

4 EPIGET Lab, Department of Clinical Sciences and Community Health, Università degli Studi di Milano, Milan, Italy

5 Department of Clinical Sciences and Community Health, Università degli Studi di Milano, Milan, Italy

6 Pediatric Unit, Fondazione IRCCS Ca' Granda Ospedale Maggiore Policlinico, Milan, Italy readers to comprehensively consider the possible negative and positive consequences of lockdown measures on children.

School closures have led to 1.5 billion school-age children and adolescents being homebound, representing over $90 \%$ of the world's student population, thereby reaching beyond borders and posing potential global issues for those affected [4]. Teachers, schools, and institutions have undertaken tremendous efforts to supply children with education at home. However, being homebound as a child should not be taken lightly. Besides the lack of knowledge-creating a possible educational backlog- also social and peer support provided by school, or sports clubs have vanished. Moreover, through social distancing, children are unable to visit their grandparents.

On top of that, the new disease Covid-19 has brought about many unknowns and thereby causing social stigmatization towards groups of people, those infected and their family [5]. Yet, children are possibly not only affected in the social or educational domain. A lockdown could have serious health consequences, such as a risk of late presentation to the hospital, frequent dental problems [6], irregular sleeping patterns, an increase in sedentary behavior, as well as an increase in- or worsening of domestic violence [1]. The French Ministry of the Interior has reported a rise in child abuse warnings of $90 \%$, substantiating the gravity of the situation [3].

On the other hand, every disaster has its learning opportunities, and so does the current Covid-19 crisis. We must not forget that the previously mentioned negative consequences might coincide with possible positive aspects. Children being homebound now have more time to spend with their caregivers, as well as with their siblings. Also, school closures might induce awareness in children that school and education is an opportunity, and school closures might lead to a decrease in negative social phenomena, such as bullying. Furthermore, the nature of the current crisis brought about national and international campaigns to raise awareness for personal hygiene. Parents are stimulated to educate children on health responsibilities and involve children in, e.g. washing hands. On top of that, in some cases, due to the lack of regular 
healthcare availability, parents are forced to rely on their skills to manage children with mild symptoms of any disease, and this might increase parents' self-confidence in maintaining the health of their children.

With this, we would like to encourage and inspire readers to take into account the possible negative consequences of the current Covid-19 crisis. But, simultaneously take into consid- eration the potential learning opportunities in the form of positive implications. Many of them have not been discussed, but they are reported in a comprehensively way, at least tentatively, in the figure. Some others might still be currently unknown. All in all, we hope that clinicians, researchers, caregivers, and any others involved will establish a broad focus towards this crisis, to facilitate a safe landing for our children.

\section{Possible consequences of Covid-19 homebound measures}

\begin{tabular}{|c|c|}
\hline \multicolumn{2}{|c|}{ Social skills and family } \\
\hline Positive & Negative \\
\hline $\begin{array}{l}\text { An increase of time spent with } \\
\text { parents. }\end{array}$ & $\begin{array}{l}\text { Lack of social and peer support } \\
\text { (especially for adolescents). }\end{array}$ \\
\hline $\begin{array}{l}\text { Increased complicity between } \\
\text { siblings. }\end{array}$ & $\begin{array}{l}\text { Lack of interaction with } \\
\text { grandparents. }\end{array}$ \\
\hline \multirow[t]{2}{*}{$\begin{array}{l}\text { Reduction of negative social } \\
\text { phenoma, such as bullying. }\end{array}$} & $\begin{array}{l}\text { Lack of social contacts outside } \\
\text { of family and school, for } \\
\text { example sport clubs. }\end{array}$ \\
\hline & $\begin{array}{l}\text { Social stigmatisation towards } \\
\text { those at risk and individuals who } \\
\text { were are or are infected. }\end{array}$ \\
\hline \multicolumn{2}{|c|}{ Hygiene and awareness } \\
\hline Positive & Negative \\
\hline $\begin{array}{l}\text { Awareness and involvement of } \\
\text { children in health care and } \\
\text { health responsibilities. }\end{array}$ & $\begin{array}{l}\text { An increase in anxiety and fear } \\
\text { about health and infection. }\end{array}$ \\
\hline $\begin{array}{l}\text { Change of opinion in anti-vax } \\
\text { parents. }\end{array}$ & \\
\hline
\end{tabular}

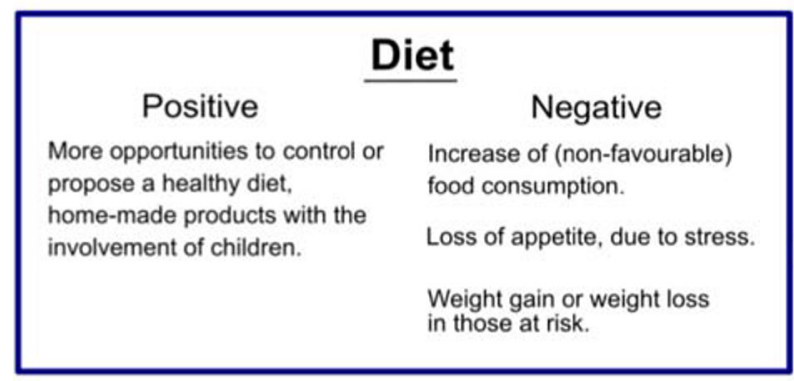

\begin{tabular}{|c|c|}
\hline \multicolumn{2}{|c|}{ Environmental health } \\
\hline Positive & Negative \\
\hline $\begin{array}{l}\text { Lockdown is boosting air quality } \\
\text { worldwide. }\end{array}$ & $\begin{array}{l}\text { Increased exposure to indoor } \\
\text { pollutants (e.g. pollutants } \\
\text { derived from cooking). }\end{array}$ \\
\hline & Reduced greenspace exposure. \\
\hline
\end{tabular}

\begin{tabular}{|c|c|}
\hline \multicolumn{2}{|c|}{ Health status } \\
\hline Positive & Negative \\
\hline \multirow{7}{*}{$\begin{array}{l}\text { Reduction of infectious diseases } \\
\text { spread especially among children } \\
\text { at risks. } \\
\text { Reduction of unnecessary medical } \\
\text { refer and increase parents' } \\
\text { awareness and self-confidence } \\
\text { in managing children with mild } \\
\text { conditions. }\end{array}$} & $\begin{array}{l}\text { Poor antigens exposition } \\
\text { (reduction in stimuli and immune } \\
\text { functioning). }\end{array}$ \\
\hline & $\begin{array}{l}\text { Risk of late presentation to } \\
\text { hospital, for example } \\
\text { complicated appendicitis. } \\
\text { Impaired production of } \\
\text { endogenous vitamin D. }\end{array}$ \\
\hline & $\begin{array}{l}\text { Increase in domestic injuries or } \\
\text { violence. }\end{array}$ \\
\hline & $\begin{array}{l}\text { Increased risk of dental health } \\
\text { issues. }\end{array}$ \\
\hline & $\begin{array}{l}\text { Increase and worsening of } \\
\text { mental health problems. }\end{array}$ \\
\hline & Irregular sleeping patterns. \\
\hline & Increase of sedentary behaviour. \\
\hline \multicolumn{2}{|c|}{ Education } \\
\hline Positive & Negative \\
\hline \multirow{2}{*}{$\begin{array}{l}\text { Improved understanding that } \\
\text { school and schoolmates are } \\
\text { an opportunity. }\end{array}$} & Educational backlog. \\
\hline & $\begin{array}{l}\text { Quality of online school lessons } \\
\text { is strictly dependent on the } \\
\text { available technology, e.g. two } \\
\text { available and appropiate devices } \\
\text { in a household of three siblings. }\end{array}$ \\
\hline \multicolumn{2}{|c|}{ Miscellaneous } \\
\hline Positive & Negative \\
\hline \multirow[t]{4}{*}{$\begin{array}{l}\text { An increased use of (social) media, } \\
\text { for studying or for activities shared } \\
\text { with peers. }\end{array}$} & $\begin{array}{l}\text { Increased screentime, health- } \\
\text { related problems and risk of } \\
\text { addiction (especially in those at } \\
\text { risk). }\end{array}$ \\
\hline & $\begin{array}{l}\text { Socio-economic consequences, } \\
\text { on parents, affecting children } \\
\text { (such as loss of job). }\end{array}$ \\
\hline & $\begin{array}{l}\text { Reduced integration for } \\
\text { immigrants and social isolation. }\end{array}$ \\
\hline & $\begin{array}{l}\text { Increased passive smoking if the } \\
\text { parents are smokers. }\end{array}$ \\
\hline
\end{tabular}




\section{References}

1. Campbell AM (2020) An increasing risk of family violence during the Covid-19 pandemic: strengthening community collaborations to save lives. Forensic Sci Int Reports 2:100089 https://www.ncbi.nlm. nih.gov/pmc/articles/PMC7152912/

2. Federal Aviation Administration. Eastern Airlines Flight 401, Lockheed Model L-1011, N310EA [Internet]. Lessons Learned. 1972 [cited 2020 Apr 17]. Available from: https://lessonslearned. faa.gov/l1_main.cfm?TabID=3\&LLID=8

3. Ministère de L'intérieur (2020) Communiqué de presse conjoint du 22 avril 2020 - Enfance en danger : Gouvernement mobilisé [Internet]. [cited 2020 Apr 23]. Available from: https://www. interieur.gouv.fr/Actualites/Communiques/Enfance-en-danger-leGouvernement-mobilise
4. UNESCO. COVID-19 Educational Disruption and Response [Internet]. [cited 2020 Apr 20]. Available from: https://en.unesco. org/covid19/educationresponse

5. UNICEF (2020) Social Stigma associated with COVID-19: A guide to preventing and addressing social stigma [Internet\}. Available from: https://www.unicef.org/documents/social-stigma-associatedcoronavirus-disease-covid-19

6. Wang Y, Zhou CC, Shu R, Zou J (2020) Oral health Management of Children during the epidemic period of coronavirus disease 2019. Sichuan da xue xue bao. Yi xue ban (in chinese). Journal of Sichuan University. Medical Science Edition, pp 151-1544

Publisher's note Springer Nature remains neutral with regard to jurisdictional claims in published maps and institutional affiliations. 